Лелик Б., канд. геолого-мінералогічних наук, Степаненко Я., інженер-геолог,

Шульга В., доктор геолого-мінералогічних наук

\begin{abstract}
ОСОБЛИВОСТІ ОЦНКИ ГІРНИЧО-ГЕОЛОГІЧНИХ ХАРАКТЕРИСТИК ВУГЛЕПОРОДНОГО МАСИВУ ПІВДЕННО-ЗАХІДНОГО ВУГЛЕНОСНОГО РАЙОНУ ЛЬВІВСЬКО-ВОЛИНСЬКОГО БАСЕЙНУ ПРИ РЕАЛІЗАЦIÏ КОМПЛЕКСНИХ ПРОЕКТІВ ВИДОБУТКУ МЕТАНУ
\end{abstract}

\author{
ОСОБЕННОСТИ ОЦЕНКИ ГОРНО-ГЕОЛОГИЧЕСКИХ ХАРАКТЕРИСТИК УГЛЕПОРОДНОГО \\ МАССИВА ЮГО-ЗАПАДНОГО УГЛЕНОСНОГО РАЙОНА ЛЬВОВСКО-ВОЛЫНСКОГО БАССЕЙНА ПРИ \\ РЕАЛИЗАЦИИ КОМПЛЕКСНЫХ ПРОЕКТОВ ДОБЫЧИ МЕТАНА
}

Показана перспектива Юго-Западного угленосного района по добыче высококачественного коксующегося угля для развития Львовско-Волынского бассейна, а также перспектива добычи метана из углегазовых месторождений. Кроме того, представлена характеристика горно-геологических условий района в сравнении с действующей частью бассейна. Поле шахты Тягловская № 1 - объект, подготовленный для реализации инвестиционного проекта по предварительной дегазации и промышленной добыче метана с быстрой окупаемостью капитальных затрат.

\title{
VALUATION OF ROCK GEOLOGICAL FEATURES OF COAL BLOCK OF SOUTHWESTERN COAL-BEARING REGION OF LVIV-VOLYN BASIN WHEN IMPLEMENTING INTEGRATED METHANE EXTRACTION PROJECTS
}

Article shows prospects in Southwestern coalfield for production of high-quality coking coal for the development of the Lviv-Volyn basin, and the prospects of methane extraction in coal-gas fields. The article also describes the features of geological conditions of the area and compares those with the productive area of the basin. 1-Tyahlivska well field is a developed object to the investment project for methane preliminary drainage and industrial production with short payback.

Ключові слова: оцінка, вугілля, метан, родовище, технологія, дегазація, інвестиційний проект.

Ключевые слова: оценка, уголь, метан, месторождение, технология, дегазация, инвестиционный проект.

Keywords: evaluation, coal, methane, field, technology, drainage, investment project.

Найперспективнішим для успішного промислового розвитку Львівсько-Волинського басейну (ЛВБ) $€$ Південно-Західний вугленосний район (ПЗВР). Проведеними геологорозвідувальними роботами на двох родовищах (Тяглівському і Карівському (Любельська вугленосна площа)) визначена можливість будівництва семи шахт на сумарну річну потужність видобутку вугілля близько 10 млн т при загальних оцінених запасах і ресурсах вугілля - 1,1 млрд тонн, що значно перевищує потенціал діючої частини басейну.

Вугілля цих родовищ, представлене в основному дефіцитними марками Ж і К, придатне для коксування. На шахтних полях Тяглівська № 1 та Любельська № 1-2 проведена детальна розвідка, оцінка запасів та їх затвердження в ДКЗ. На шахтних полях Тяглівська 2-3 та Любельська 3, 4, 5 стан геологорозвідувальних робіт відповідає стадіям попередньої розвідки та пошуково-оцінювальних робіт. На даний час компанія «Сі-Сі-Ай-Любеля», що належить компанії «Стелекс» (США), будує шахту Любельська № 1-2. Вугілля цієї шахти високоякісне, коксівне, низькозольне та малосірчисте - конкурентоздатне на ринку навіть за європейськими екологічними нормами.

На діючих шахтах басейну, особливо західної групи, яка належить до Червоноградського геологопромислового району (шахти № 6, 7, 10 «Великомос- тівські» понадкатегорійні за метаном), газоносність становить 10-15 м³/т.с.б.м. Газоносність зростає у західному напрямі. Родовища ПЗВР - метановугільні з газоносністю 20-27 м³/т.с.б.м. (окрім шахтних полів 1-2 Любельські).

Переважаючим компонентом природних газів вуглегазових товщ ПЗВР є метан (від 70 до 98\%). Поряд 3 метаном до природної газової суміші входять азот (від 2 до 30\%), вуглекислий газ (1-2\%), важкі вуглеводні, гелій та інколи водень. 3 глибиною, від поверхні метанової зони, спостерігається ріст вмісту метану з одночасним зменшенням вмісту азоту та вуглецю. Важкі вуглеводні представлені перш за все етаном (від слідів до декількох відсотків), пропаном (соті, десяті частки відсотка), рідко до 1\%. Бутан і пентан виявлені лише в поодиноких пробах газу (тисячні, соті інколи десяті частки відсотка). 1986 року в ДКЗ СРСР у вугільних пластах поля шахти Тяглівська № 1 були затверджені запаси метану у вугіллі за категорією $\mathrm{C}_{2}$ в кількості 2,95 млрд м³.

Більш детально зупинимося на гірничо-геологічних умовах залягання родовищ, їхніх характеристиках та особливостях можливого впливу на реалізацію комплексних проектів промислового видобутку метану. Без проведення успішної дегазації шахтних полів, як відомо, прогнозувати безпеку робіт на шахтах та нарощувати видобуток вугілля неможливо. 
У геоструктурному плані ПЗВР знаходиться у зоні активного впливу «переходу» Східно-Європейської платформи в передовий прогин Карпатської геосинкліналі. Такі особливості розміщення родовищ перспективної частини басейну враховуються під час аналізу результатів досліджень, а також у ході використання методу аналогії з діючими родовищами басейну для об'єктивної оцінки та прогнозу гірничогеологічних умов залягання вугільних пластів у ПЗВР.

За результатами проведених досліджень встановлено, що кількість виявлених свердловинами диз'юнктивних порушень наростає від діючої частини басейну у бік ПЗВР, причому зростають їхні амплітуди, змінюеться переважаючий тип від «насувних» до «скидових». Такі закономірності проявляють себе навіть у межах Тяглівського родовища і Любельської вугленосної площі, де на останній кількість виявлених скидів утричі вища.

Така «скидова» специфіка, особливо в контурах шахтних полів Любельська № 1-2, де навіть перше розділення полів (до їх об'єднання) мало природну межу - по скиду, на наш погляд, зумовила природну дегазацію промислових вугільних пластів, які знаходяться у зоні газового вивітрювання, за винятком північно-західної частини вугільного пласта $n_{7}$ у старих межах шахтного поля Любельська № 2. За віком ці порушення відносяться до альпійського тектогенезу. Механізм утворення представляє собою розвантаження (розкриття) у динамічно напруженій перехідній області, яка чітко контролюється трьома зонами насувів: Нестеровською, Бутинь-Хлівчанською та Белз-Милятинською, які мають загально-карпатське простягання. 3 огляду на це, шахтне поле Любельська № 1-2 знаходиться у сприятливих за газовим фактором умовах для видобутку вугілля. За останніми висновками ТЕО, складеного ДВАТ «Дніпродіпрошахт», на потужному гірничо-видобувному комплексі Любельська № 1-2, який будується, очікується можливий річний видобуток вугілля 3,5-4 млн тонн, що у 2-3 рази перевищуватиме існуючий на сьогодні видобуток у басейні (зараз працюють 11 шахт). Інші шахтні поля ПЗВР потребують реалізації спеціальних проектів для проведення робіт з дегазації та зменшення впливу «газового фактора».

Лабораторні дослідження вміщуючих вугільні пласти гірських порід показали, що в зонах тектонічних порушень фізико-механічні властивості порід характеризуються пониженою міцністю, що пов'язано 3 підвищеною тріщинуватістю, пористістю та водонасиченням порід. Значення фізико-механічних властивостей основних вміщуючих вугільні пласти порід і їхня порівняльна характеристика наведені в табл. 1 [1].
У цілому показники міцності знаходяться у межах співставних норм, хоча помітне закономірне зростання їх величини на південний захід, що пояснюється зростанням метаморфізму в цьому напрямі.

Крім цього, при складанні проектів дегазації для шахтних полів ПЗВР необхідно враховувати специфіку буріння свердловин, яка буде пов'язана зі ступенем поширення мезозойських порід як по площі, так і за товщиною покладів. Ці породи залягають на продуктивних кам'яновугільних відкладах і в різних ділянках басейну певною мірою негативно впливають як на проведення бурових робіт, так i, безперечно, на гірничо-експлуатаційні характеристики шахт. За вказаними особливостями ПЗВР суттєво відрізняється від діючої частини ЛВБ $[1,4]$. Відповідно до ступеня впливу мезозойських відкладів як на буріння, так і на умови експлуатації, всю площу басейну, яка експлуатується та готується до будівництва нових шахт, можна розділити на ділянки трьох типів: слабкого, помірного і значного впливу мезозойських порід. Найбільш детально вивчені ділянки перших двох типів, оскільки вони знаходяться в межах діючої частини ЛВБ (рис. 1).

Ділянки слабкого впливу характеризуються відносно малими потужностями (300-450 м) порід крейдяної системи і займають більшу частину Нововолинського і Червоноградського геолого-промислових районів (до 80\%) та частину ПівденноЗахідного вугленосного району (до 30\%). У межах перших двох ділянок знаходиться переважна більшість діючих шахт басейну.

Відмінною рисою ділянок помірного впливує присутність у розрізі мезозойських порід малопотужної товщі (5-28 м) юрських порід, представлених в основному теригенними обводненими породами. Уході виконання бурових робіт при безпосередньому контакті з породами або на незначних відстанях вони набувають властивостей текучості, що призводить до непередбачуваних ускладнень (обвали, виноси піску та пливуна). В межах ПЗВР ділянки цього типу займають порівняно незначну площу крайньої північнозахідної і південної частини Тяглівського родовища.

Ділянки значного впливу поширені переважно в межах Південно-Західного вугленосного району і характеризуються підвищеними потужностями крейдяних відкладів (550-650 м), а також значно більшою площею поширення (до 60\%) і потужностями юрських порід (від 50 до 150-200 м). У межах цієї зони юрські відклади представлені трьома різнорідними товщами: нижньою - теригенною (сокальська світа), що становить до 40-50\% товщі; перехідною -

\section{Таблиця 1}

\begin{tabular}{|c|c|c|c|}
\hline \multirow[t]{2}{*}{ Порода } & \multicolumn{3}{|c|}{ Межа міцності на стиснення, $10^{-5}$ Па (від - до) } \\
\hline & $\begin{array}{c}\text { Діюча частина Львівсько- } \\
\text { Волинського басейну }\end{array}$ & Тяглівське родовище & Любельська площа \\
\hline Пісковик & $567-746$ & 820-2096 & $576-1633$ \\
\hline Алевроліт & $448-517$ & $348-782$ & $193-1004$ \\
\hline Аргіліт & $405-445$ & $168-515$ & $159-497$ \\
\hline
\end{tabular}




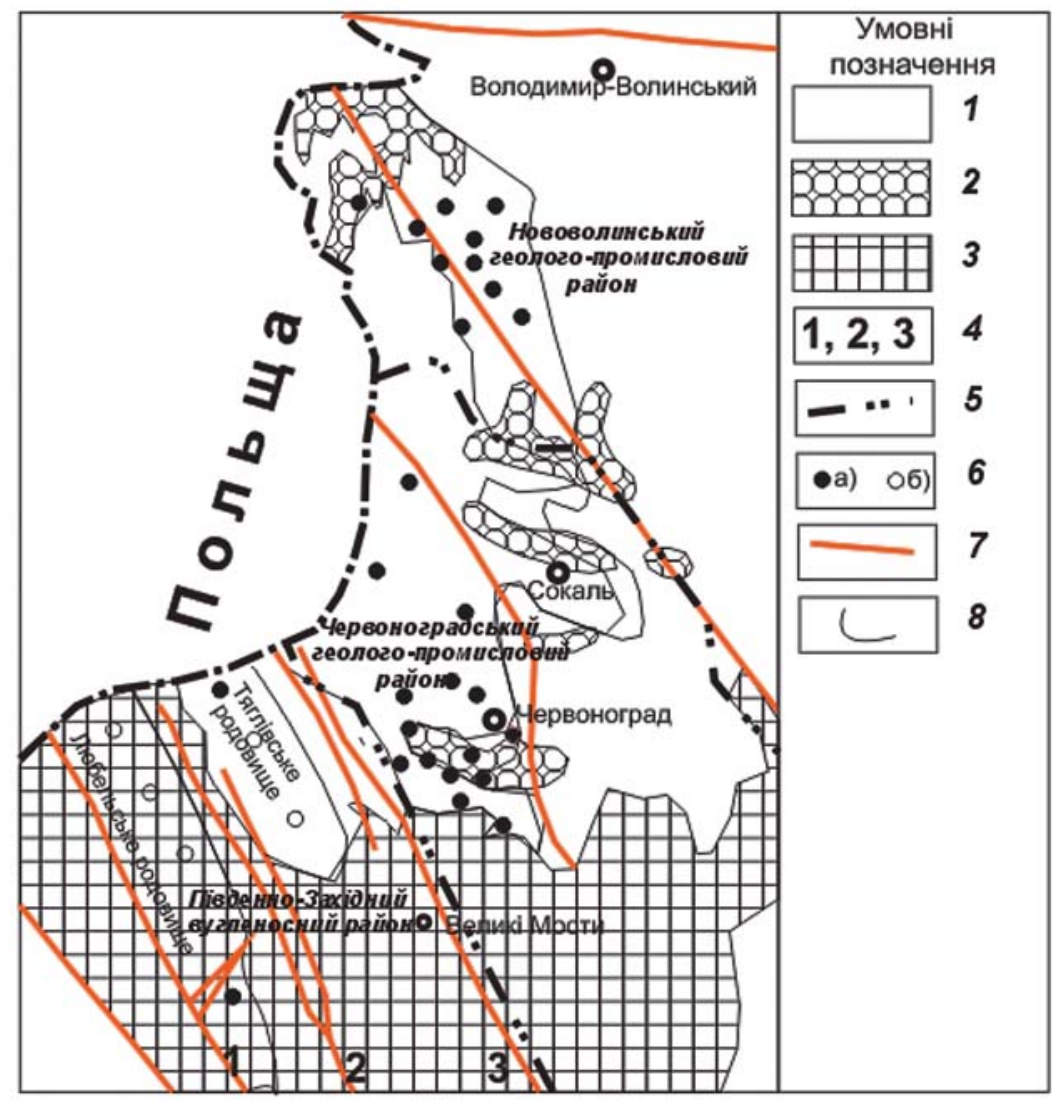

Рис. 1. Схема типізації площі Львівсько-Волинського басейну за ступенем впливу мезозойських порід на умови розробки вугільних пластів та реалізацію дегазаційних проектів: 1 - зона слабкого впливу; 2 - зона помірного впливу; 3 - зона значного впливу; 4 - $(1,2,3)$ - зони насувів Нестеровська, Бутинь-Хлівчанська і Белз-Милятинська; 5 - межі геолого-промислових та вугленосних районів; 6 - шахти діючі, закриті та передані в промосвоєння (а) і ті, що розвідуються (б); 7 - тектонічні порушення; 8 - контури родовищ

теригенно-карбонатною (рава-руська світа), породи якої становлять 20-30\% товщі; верхньою - карбонатною (нижневська світа), яка становить 20-30\%.

Багаторічні геологорозвідувальні та експлуатаційні роботи дозволили повною мірою вивчити геологічні та гідрогеологічні характеристики крейдяних відкладів та їхній вплив на умови бурових та експлуатаційних робіт у басейні. Фільтраційні властивості туронських і нижньосенонських відкладів у межах всього басейну дуже низькі. Товща цих відкладів - потужний водотримач, який розділяє основний верхньосенонський і нижчезалягаючі водоносні горизонти, що, за умови ізоляції цього горизонту обсадними трубами, не справлятиме суттєвого впливу на виконання робіт з дегазації вуглепородної товщі.

Тріщинуваті мергелі сенонського над'ярусу на глибинах 20-90 м - єдиний найбільш водозбагачений горизонт крейдяних порід. Цей горизонт є основним для питного водозабезпечення населення. Його проходка буровими роботами особливих нарікань не викликає і проводиться на «самозамісі» бурового розчину. Єдиною і найважливішою умовою проходки даних горизонтів $€$ беззаперечне виконання вимог екологічної безпеки, щоб не допустити забруднення горизонту та виконати обсадку свердловини. Проходка стовбурів свердловин у нижній частині слабо тріщинуватих і малообводнених мергелів сенону і в туронській товщі здійснюється без значних водопроявів та ускладнень.

На реалізацію дегазаційних проектів, як і на проведення гірничих робіт у ПЗВР, будуть впливати в основному породи теригенної та теригенно-карбонатної товщі. У процесі експлуатації поблизу виходів вугільних пластів на поверхню карбону зона впливу гірничих робіт (зона водопровідних тріщин) буде спостерігатись по всій потужності теригенної товщі (40-90 м), яка гідравлічно зв'язана 3 породами теригеннокарбонатної товщі. 3 цією частиною геологічного розрізу пов'язані підвищені водоприпливи у гірничі виробки, обвали, виноси піску і пливуна та ін. Для ефективного проведення дегазаційних робіт у даних умовах необхідно передбачати заходи зі зниження статичного рівня водоносних горизонтів, створення депресії, щоб таким чином сприяти припливу метану до свердловин 
і проведенню ефективної дегазації. У ході робіт з видобутку вугілля та відробки верхніх пластів під юрськими відкладами передбачається створення цілої системи дренажних свердловин з метою осушення цієї водонасиченої товщі та максимально повної відробки вугілля з продуктивних пластів.

Найбільш прийнятними технологіями, які можна рекомендувати для використання під час дегазаційних робіт, є методи, розроблені спеціально для гірничо-геологічних умов Львівсько-Волинського та Донецького басейнів [2, 3]. Проведення супутньої дегазації можна рекомендувати для діючої групи шахт Червоноградського геолого-промислового району, що прилягає до Белз-Милятиської зони насувів № 6 , 7, 10 ВМ. Особливо це стосується шахти Степова (№ $10 \mathrm{BM}$ ), яка характеризується високою газоносністю і є небезпечною за газовим фактором.

Для проведення попередньої дегазації найбільш підготовлене шахтне поле Тяглівська № 1. Природні умови для реалізації технології [2] € максимально сприятливими. Вугільний пласт $n_{6}{ }^{1}$ повсюдно залягає нижче основного шахтопласта $n_{7}{ }^{\mathrm{B}}$ на відстані 25-30 м, має площадне розповсюдження, витриманий за товщиною, яка коливається в межах 0,35-0,45 м, і його можна використати для підземної газифікації (випалювання) 3 метою інтенсифікації гравітаційного розвантаження вищезалягаючої вуглепородної товщі у випалену зону та створення тим самим дрібної штучної тріщинуватості, що сприятиме максимально повній дегазації вуглепородного масиву. Беручи до уваги сприятливі природні геологічні умови будови родовища, високу газоносність шахтного поля Тяглівська № 1, а також спеціально розроблену для цих умов технологію попередньої дегазації, цей інвестиційний проект можна оцінити як надзвичайно привабливий. Розрахункова окупність капітальних витрат на буріння дегазаційних свердловин та проведення газифікаційних робіт лише за рахунок реалізації високоякісного газу метану за сучасними ринковими цінами не перевищуватиме одного року.

Таким чином, ПЗВР представляє собою значний потенціал для видобутку високоякісного вугілля. По одній тільки шахті Любельська № 1-2, яка будується, передбачається річний видобуток на рівні 3,5-4 млн тонн, що перевищуватиме сьогоднішні показники видобутку вугілля ЛВБ у 2-3 рази. Крім видобутку вугілля у ПЗВР можливий промисловий видобуток метану, особливо у ході реалізації проектів попередньої дегазації, впровадженню яких сприяють наявні гірничогеологічні умови та спеціально створені технології. При реалізації проектів шахтного будівництва, бурінні свердловин та дегазації слід враховувати також наявність перекриваючих кам'яновугільні обводнених юрських відкладів, що матимуть негативний вплив і вимагатимуть застосування запобіжних заходів безпеки робіт. У статті наведено характеристики цих відкладів та схема їх поширення.

1. Горно-геологическая характеристика Львовско-Волынского угольного бассейна / Шульга В. Ф., Караваев В. Я., Лелик Б. И. и др. // Уголь Украины. - 1995. - № 12. - С. 2-9.

2. Лелик Б.І. Патент на корисну модель «Спосіб попередньої дегазації вугленосної товщі». № патенту 35282 від 10.09.2008. № заявки и200804705.

3. Лелик Б.І. Патент на корисну модель «Спосіб супутньої дегазації вуглепородного масиву діючих шахт». № патенту 76540 від 10.01.2013. № заявки u201206875.

4. Прогноз гірничо-геологічних умов та газоносності вугільних пластів Південно-Західного вугленосного району ЛьвівськоВолинського басейну / Б. І. Лелик, М. Я. Решко, Є. Й. Гірний, Я. Г. Степаненко // 1-ші читання пам'яті академіка І. В. Забігайла: Тези доповідей. - Львів: ІГГГК НАН України. - 1997. 